\title{
On the Problems in the Establishments and Sustainable Development of Sci-Tech Banks and Countermeasures
}

\author{
Mingyun $\mathrm{Ke}^{1, a}$,Qingjun Meng ${ }^{2, \mathrm{~b}}$ and Binglin Lai ${ }^{3, \mathrm{c}}$ \\ ${ }^{1}$ Business School of Hohai University,Nanjing,China \\ ${ }^{2}$ Business School of Hohai University,Nanjing,China \\ ${ }^{3}$ Dayu School of Hohai University,Nanjing,China

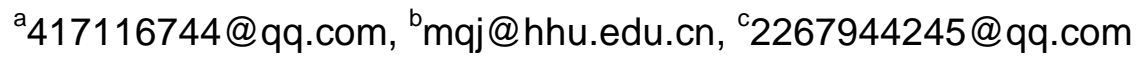

\begin{abstract}
Keywords: Sci-tech banks; High-tech SMEs; Immaterial assets; Value assessment
Abstract. The establishments of banks of science and technology facilitate the mitigation of the difficult financing by the science and technology-oriented medium and small-sized enterprises, which are characterized by high risks, high investments and high-tech. Sci-tech banks can provide the high-tech SMEs with such professional financing services as financing with intangible assets mortgage. During their developments, sci-tech banks are faced with such problems as the barriers in the legal system, the low level of risk control and low market notability. Regarding the case analysis of the Bank of Silicon Valley, it is necessary to take such countermeasures as intensifying the support strength, consolidating risk control and elevating market competitiveness.
\end{abstract}

\section{Introduction}

Sci-tech banks refer to the banks providing financing services to high-tech enterprise, which play a big role in the financing process of high-tech SMEs, and it is gradually concerned by country and society. The main task of sci-tech banks is to conduct venture investment and provide financing services to high-tech enterprise. However,innovation-oriented high-tech enterprise is always accompanied by high-risk, so it is called Riskbank in the United States. Accelerating the development of sci-tech banks is of great significance to the development of China's national economy ${ }^{[1]}$. From the macroscopic perspectives, emerging sci-tech banks drive the development of credit, investment fund along with financing, together propelling the upgrading of innovative economic development and transition. A remedy for the headache tech departments unfamiliar with the finance system face and vice versa, it makes up for the information imbalance between tech firms and finance services ${ }^{[2]}$.

The high-tech SMEs are faced with such problems with tremendous operational risks, short product cycles, rapid technological innovations, a lack of the intangible assets mortgages and difficulties in financing. The current commercial banks and policy banks attach importance to such services as the tangible assets mortgages; however, it is usually difficult for the high-tech SMEs to obtain the loans by the commercial banks due to a lack of sufficient tangible assets mortgages. Although such enterprises are endowed with such intangible assets as the intellectual property rights, since it is difficult to conduct accurate evaluations on their values, it is difficult to the SMEs to have financing from the commercial banks.

\section{Related research}

The theory of establishing the sci-tech banks derives its origin from the research on the high-tech SMEs financing issues. S.Joseph,W.Andrew (1981) argue that the main reasons for high-tech SMEs' difficulty in financing are the information asymmetry and opaque, financial irregularities, fluctuations in operating, which leads to the high costs and deep difficulty obtaining information ${ }^{[3]}$. U.Berger ${ }^{[4]}$ and W.Strahan ${ }^{[5]}$ find that large financial institutions are usually reluctant to provide loans to high-tech SMEs with opaque information, while the small scale financial institutions of low complexity tend to provide a loan for the high-tech SMEs. In recent years, many domestic scholars have begun to study 
and explore the technology bank. H.M.Zhu and C.W.Zhao (2012) definite the sci-tech banks based on four aspects: the role definition, business model, operation nature and specific function ${ }^{[6]}$. While Y.W.Duan (2013) believes that those providing platform with risk financing business for the sci-tech banks can be defined as the sci-tech banks too ${ }^{[7]}$.

A.D.Niu, B.L.Zhang consider that (2014) the sci-tech banks are the collectively of professional banks and financial institutions which combine technological innovation and financial innovation, providing services for innovation oriented enterprises, high-tech enterprises, venture capital enterprises and venture capital projects that possess unique development cycle and the demand characteristics $^{[8]}$. Y.C.Shao and G.L.Ren (2014) believe that to obtain the effective development in Chinese science and technology, the problems of the property right orientation must be solved firstly ${ }^{[9]}$. S.Gao (2013) holds the view that the professional market positioning, the financial service provided for entrepreneurial firms in different stages and different industries, the unique investment pattern, and the strict control of risk are the main reasons for the success of Silicon Valley Bank ${ }^{[2]}$. Y.C.Shao and G.L.Ren (2014) believe that the efficient risk control system contributes much to the success, and in the process of investing in sci-tech banks, Silicon Valley Bank developed a series of systems in lending limits ,mortgage guarantee, isolation of risk and other aspects, which made it feasible to avoid the risk of technological credit ${ }^{[9]}$. The researches above reveal the features of the definition of sci-tech banks and the reasons for the success of Silicon Valley Bank. Meanwhile, the researches point out the problems that occurred when sci-tech banks developed in China, and make some targeted suggestions, which give impetus to the development of the bank. In short, these analyses are reasonable. But if we consider the reality and take all factors we can find problems in the banking establishment and development of sci-tech banks.

\section{The establishment and development of sci-tech banks}

China's sci-tech banks come into appearance in the form of science and technology credit cooperatives and old fashioned technology branch ${ }^{[10]}$. In 2000, China Construction Bank, Shenzhen Keyuan branch was established in Shenzhen, of which the first Venture loan amount totaling 500 million yuan successfully met the financing needs of many high-tech SMEs. In 2002, the Commercial Bank of Nanning set up a technology bank sub-branch to provide financing support for high-tech SMEs. Since 2004, the state has introduced a series of policies including Directive opinions on the improvement and strengthening of the financial services of high-tech enterprises in the commercial banks ${ }^{[11]}$. In 2009 , the sci-tech bank specializing in serving high-tech SMEs, that is, China Construction Bank Corp Chengdu branch was established.In 2012, Technology Bank of Yinzhou, was founded, Planning to invest 500 million yuan to support the development of high-tech SMEs. In the same year, China's first joint venture bank which focuses on service and science and technology innovation, SPD Silicon Valley Bank(SSVB), was established in Shanghai. Two big shareholders, Shanghai Pudong development bank co., LTD.and silicon valley bank co., LTD., hold 50\% stake each. In 2013, the first sci-tech bank in Dongying, Shandong was established,aiming at providing technical credit services. On December, 2015, the first "Technology Bank" of Shandong Province was founded in Laiwu, which successfully pushed out series of credit products to high-tech SMEs ${ }^{[12]}$. As a kind of newly-developed financial organizations, sci-tech banks are experiencing prosperity in China, but some problems are also involved in the real operation condition, as sci-tech banks fail to play the same role in addressing financing problems of high-tech SMEs as Silicon Valley Bank does. The development is shown in Table 1.

The most famous sci-tech bank in the world is the Silicon Valley Bank. It was established in 1983 in the United States, with the total assets of more than $\$ 20$ billion in 2016 , and has provided $\$ 2.6$ billion of loans for venture capitalists and startup businesses through 27 U.S. offices, 3 international subsidiaries and an extensive network of business relationships in Asia, Europe, India and Israel. Silicon Valley Bank has a clear and precise customer orientation, mainly focusing on high-tech SMEs. After years of development, Silicon Valley Bank has formed a unique set of mature profit model, that is, 
a combination of equity investment and credit business, and a binding model of equity and debt ${ }^{[13]}$. Close combination with the risk investment institutions has improved its competitiveness. The information is shown in Fig.1.

\begin{tabular}{|c|c|c|}
\hline Established time & Established location & Name of sci-tech banks \\
\hline 2000 & $\begin{array}{c}\text { Shenzhen,Guangdong } \\
\text { Province }\end{array}$ & $\begin{array}{c}\text { China Construction Bank,Shenzhen Keyuan } \\
\text { branch }\end{array}$ \\
\hline 2002 & $\begin{array}{c}\text { Nanning,Guangxi } \\
\text { Province }\end{array}$ & $\begin{array}{c}\text { Nanning Commercial Bank,technology } \\
\text { sub-branch }\end{array}$ \\
\hline 2009 & $\begin{array}{c}\text { Chengdu,Sichuan } \\
\text { Province }\end{array}$ & $\begin{array}{c}\text { China Construction Bank Corp Chengdu } \\
\text { branch of science and technology }\end{array}$ \\
\hline 2012 & $\begin{array}{c}\text { Yinzhou,Zhejing } \\
\text { Province }\end{array}$ & Sci-Tech Bank of Yinzhou \\
\hline 2013 & Pudong,Shanghai & SPD Silicon Valley Bank(SSVB) \\
\hline 2015 & $\begin{array}{c}\text { Dongying,Shandong } \\
\text { Province }\end{array}$ & Sci-Tech Bank Bank of Dongyin \\
\hline Province & Sci-Tech Bank Bank of Laiwu \\
\hline
\end{tabular}

Table 1. Relevant information about some sci-tech banks in China

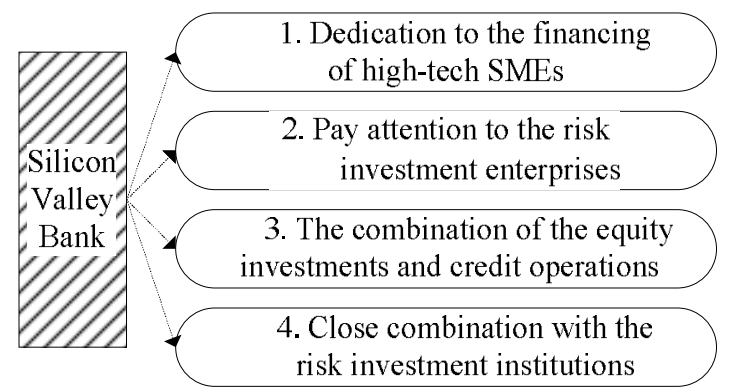

Fig.1 Strategies for sustainable development of Silicon Valley bank

\section{Problems in the establishment and development}

Sci-tech banks are facing institutional obstacles in their development. The sci-tech banks should include the two-way function of credit and investment, while China's current Commercial Bank Law is incompatible with the bank equity investment. According to the Commercial Bank Law of our country, commercial banks shall not invest in non-bank financial institutions and enterprises. In addition, A commercial bank should decide the interest rates of loans in accordance with the upper and lower limits of loan interest set by the People's Bank of China. These provisions mean although China's sci-tech banks adopt the very similar business model and source of profits as ordinary commercial banks, they have to take relatively high risks of high-tech middle and small-sized enterprises (high-tech SMEs), which is obviously not conducive to their sustainable management. At present, our country is still lack of sound regulations and policies, which is not beneficial to developing sci-tech banks.

The risk level control of sci-tech banks is not high. The high-tech SMEs are mainly engaged in the development of high-tech projects, characterized by high risk, high investment, and high returns. And their major assets concentrate on patents, trademarks, and other intangible assets, hard to carry on value assessment. Due to their small scale, low level of credit and asymmetric information, it is more difficult for banks to accurately assess the risk degree of enterprises, creating great risks to the loan business of sci-tech banks. Currently, sci -tech sub-branch banks in China generally establish risk 
compensation mechanisms with the local government and security agencies in risk controls, paying attention to the post risk-sharing. This shows China's sci-tech banks still stop their risk prevention and control at an ex post stage, and fail to do well in risk prediction and prevention, increasing the operational risk of sci-tech banks.

Lack of compound professional talents. As the service targets of sci-tech banks are high-tech enterprises, banks businesses not only involve in the professional knowledge of finance and financial management, but also concern asset valuation, risk investment, program design, machinery manufacturing and other disciplinary knowledge, which requires sci-tech banks to hire a large number of compound professional talents. In fact, our sci-tech banks are badly short of the talents who understand the market and can dock with the market effectively, and are also lack of cooperation with universities and scientific research institutions, not favorable for the improvement of their professionalism.

Sci-tech banks have a lower popularity. At present, sci-tech banks have a lower popularity and a small scale, so most people do not know them clearly. They are weak in propaganda, and do not make full use of the news media and other mass media. They are lack of the publicity on their own core values and business philosophy, as well as the public supervision on their daily operations. As a result, people do not have the appropriate knowledge of specifications on sci-tech bank's loan business. At present, compared with other commercial banks, sci-tech banks lack sources of funds, resulting in a small scale. Private capital for the investment of sci-tech banks is not enough, and sci-tech banks are not familiar with the technical specifications of the bank loan.

\section{Countermeasures for establishment and development}

Increasing policy support and reducing institutional barriers. As the "invisible hand" in the market economy, the government plays an irreplaceable role in the economic growth. Therefore, the government should introduce the appropriate policy to promote the sustainable development of sci-tech banks. First, the government should establish a risk compensation mechanism. For example, the government can provide financial fund as provisions of risk according to a certain percentage of the loan balance on science and technology for high-tech SMEs from sci-tech banks, which can be regarded as the capital pool to offer the risk compensation for technology loans of sci-tech banks. Second, the government should intensify efforts to financial reform, such as allowing sci-tech banks to engage in equity investment. Third, the government should perfect the regulatory legal system, such as formulating Sci-tech Banking Act, to create a favorable external environment for the healthy development of successful operation of sci-tech banks.

Strengthening the risk control of sci-tech banks. Firstly, the risk control system should be improved continually, including the formulation of proper operating guidelines and the internal control system for sci-tech banks, as well as suitable assessment method, risk evaluation criteria and management standardization for high-tech enterprises. Secondly, the risk control of sci-tech banks before issuing loans should be strengthened, the credit risk assessment system of high-tech enterprises should be perfected, and whether to issue loans and the specific loan interest rates should be determined. After the issuance of loans, sci-tech banks should keep supervising the operation status of high-tech enterprises, timely conduct risk assessment on sci-tech loans, and take different management methods for sci-tech loans of various risk levels. Finally, the cooperation with venture capital institutions should be enhanced to reduce the risk of loans.

Intensifying the cultivation of compound professional talents. Now talents play a great role in various aspects, including in sci-tech banks. Compound professional talents should be cultivated with joint efforts of the society and the bank. At the social level, the colleges and training institutions should focus on the key areas of strategic emerging industry and modern service industry to equip compound professional talents with the knowledge of finance, accounting, science and technology, law and predicting and managing all kinds of risks; at the bank level, staffs' ability of risk identification and 
control on high-tech enterprises can be increased through pre-job training and job rotation to reduce operational risks of sci-tech banks.

Stepping up sci-tech bank's publicity to raise its popularity. Sci-tech banks should make full use of mass media like the news media to step up their publicity, so that they can be understood by the public better with their increasing popularity. They should increase the publicity on their own core values and business philosophy, as well as the public supervision on their daily operations, so as to enhance the impartiality and transparency of loans to make loans more normative and reasonable. They can also consolidate their publicity through the stock and other means. In addition, sci-tech banks also need to increase the bank shares and expand the channels for capital sources, and usually these are conducted in the form of the cooperation between the banks and the risk investment institutions, and the activities include the introduction of private capitals, the intensification of investments, the expansion of the banks' capital capacities and the active participation in investment promotion and capital introduction.

\section{Conclusions}

There are few sci-tech banks in our nation. The nation should intensify the subsidies and policy support for the sci-tech banks; sci-tech banks should attach importance to the training of compound talents so as to elevate their own capacities. There exist competitions between the sci-tech banks and other commercial banks. Due to their low notability, it is very difficult for them to promote their businesses. Most sci-tech banks are concentrated in such economically developed areas as the coastal region or metropolitans and there is a scarcity in such under-developed areas as the mid-and western regions. It is estimated that in the future each capital city will have one to two sci-tech banks.

With the nation's promulgations of more preferential policies as well as the development of the high-tech SMEs, the private capitals will intensify the investments to sci-tech banks, so there will be more and more opportunities for the sustainable development of the sci-tech banks.

\section{Acknowledgements}

This work was financially supported by the professors in Business School of Hohai University. The professors offered me a lot of information about the issue, which help me finish the paper.

\section{References}

[1]Y.F. Lin, Y.J. Li, Economic Research, vol. 4(2003), p. T00 ( In Chinese )

[2]S.Gao, Technoeconomics \& Management Research, vol. 5, p. 84-87 ( In Chinese )

[3]S.Joseph, W.Andrew: American Economic Review, vol. 71(1981):p. 393-410

[4]A.N.Berger, G.F.Udell. The Economics of small business finance, vol. 22(1998):p. 613-673

[5] P.E. Strahan, J.P. Weston, Journal of Banking and Financing. Vol. 22(1998):p. 821-845

[6]H.M. Zhu , C.W. Zhao, Q.W. Zhao. Reform of the economic system. Vol. 3(2012):p. 163

[7]Y.W. Duan: Times Finance. (2013) ( In Chinese )

[8]A.D. Niu, B.L. Zhuang, Y.R.Tang. Operation and management of Commercial Bank,vol.6(2014):35 ( In Chinese )

[9]Y.C. Shao, G.L. Ren. Journal of Sichuan University of Science \& Engineering (JRC Social Science Edition), vol. 29,6(2014):p. 46 ( In Chinese )

[10]Information on http://www.cbrc.gov.cn/index.html

[11]Information on http://www.gov.cn/zhengce/2015-08/30/content_2922393.htm 
[12]Information on http://wzdig.pbc.gov.cn:8080/dig/ui/search.action?q

[13]X.Y. Li, Journal of Central University of Finance \& Economics, vol. 11(2015):p. 45-52 ( In Chinese ) 